\title{
Reporting Structures and Financial Efficiency among Selected County Governments
}

\author{
Psirmoi Chebasa Mercy Dr.Rashid Fwamba Dr. Brian Singoro \\ School of business and economics, Department of Economics Finance and accounting, Kibabii University
}

\begin{abstract}
Internal auditors face several obstacles including limited of independence, limited access to records as well as support and recognition by the management. The importance of internal auditing within the county government is underscored by noted irregularities including records inaccessibility, poor reporting structures and even incompetence of internal auditors within the county government expenditure. Therefore, the focus of this study was to examine the influence of internal audit independence on the financial efficiency of selected county governments. The study was guided by the specific objectives of; to evaluate the influence of reporting structure on the financial efficiency of selected county governments. The study targeted 423 respondents from the 9 county Audit Committee members of the 47 county governments in Kenya. The researcher sampled 126 respondents from the 14 (30\% of the 47 targeted population of counties) counties which was purposively sampled regionally. Purposive sampling technique was used to get the 14 county governments. The survey involved collecting information by administering questionnaires. Data collected was descriptively analyzed using SPSS. Results was summarized using tables and presented in form of pie charts, graphs, and bar charts. The means of reporting structures and Financial Efficiency of County Governments were regressed. Findings revealed that the relationship of reporting structures and Financial Efficiency of County Governments variables which was linear, positive and significant. The correlation coefficient $(\mathrm{R})$ of 0.470 implied a relatively weak relationship of reporting structures and Financial Efficiency of County Governments. The coefficient of determination, R-square of 0.221 implied that $22.1 \%$ of the variance in Financial Efficiency of County Governments was accounted for by reporting structures with the significance value of $p=0.000$ which is less than 0.05 . This findings will be of use in policy formulation, industry practice and research.
\end{abstract}

Keywords: Reporting Structures, Financial efficiency, Internal audit independence

DOI: $10.7176 / \mathrm{RJFA} / 10-19-02$

Publication date:October $31^{\text {st }} 2019$

\subsection{Background to the Study}

Globally internal audit is a major contributor to financial efficiency and effectiveness in government agencies. For example, Alzeban (2014) examined the effectiveness of the internal audit function within Saudi Arabia government. The study noted that there were factors that contributed to the perceived effectiveness of the internal audit function in Saudi Arabia including competence, independence, size of the function, the relationship between internal and external audit and the extent of management support for the internal audit function and also as to the role of management support for the internal audit function as a key driver of the effectiveness of the function. In the context of Malaysia, Hammad et al., (2012) the lack of qualified, skilled and experienced internal auditors greatly reduced the effectiveness of the internal audit function within the public sector in Malaysia. There were few internal auditors in the government with 10 years of experience.

The effectiveness of the internal audit function in Africa faces various challenges. In Ghana, Affum (2011) notes that the internal audit function is faced with challenges such as poor image, communication challenges, incompetent staff, and lack of independence from the management staff. In the context of the internal audit image, the internal auditors are often perceived as the enemies of the management as opposed to seeing the contribution that the internal audit function plays. On the other hand, Ogechi (2013) notes that the effectiveness of the internal audit function in Nigerian local government was curtailed by the lack of proper segregation and proper assignment of duties as well as shortage of qualified staff to carry internal audit and accounting duties. Other challenges included the lack of the implementation of routine audit reports by appropriate authorities and the inadequacy of the internal control systems.

Mihret and Yismaw, (2007) in their case study on Ethiopian public Universities argue that internal audit recommendations are not afforded enough management attention and support which adversely affect the effectiveness of internal audit. Moreover, lack of mechanisms in place to follow up the implementation of internal audit recommendations; absence of strategic plan and consistent documentation styles for audit work, lack of resources, poor leadership for internal audit function (IAF), absence of appropriate framework to measure IAF performance, and lack of competent personnel are also some challenges of internal auditors (Mihret and Yismaw, 2007; belay, 2007).

In Kenya, the public finance management provisions in the new Constitution were significantly influenced by the need to correct past executive excesses and abuses. Chapter 12 of the new Constitution begins in Article 
201 with guiding principles and a framework for public finance, which if strictly adhered to can alter policy formulation and the management of public resources for the better (Kirira, 2011). Among the key principles are requirements that there should be: Openness, accountability and public participation; Promotion of equity, meaning that the tax burden is shared fairly at both national and county levels; Public expenditure that promotes equitable development and addresses marginalized areas and groups; Equitable sharing of debt benefits and burden between current and future generations; Prudent and responsible use of public resources and Responsible public financial management with clear fiscal reporting (Kirira, 2011).

The set-up of internal audit function has been provided for under the Public Financial Management Act of 2012 and the Public financial management regulations of 2015. This law and the implementing regulations also accommodate prior guidance provided through Treasury circular AG/3/080/6/(61) of 2000 on the establishment of Audit committees in all Ministries, departments and agencies of the central government, circular 16 of 2005 which provided detailed guidance on internal auditors role in enhancing oversight, governance, transparency and accountability and circular 18 of 2005 that provided a detailed guide to management action on internal audit reports (ICPAK, 2015).

Ongeri et al., (2015) studied the effectiveness of the internal audit function within the Kisii Local Government which established the function was not adequately discharging its mandates. On the other hand, Masika (2013) examined the effect of the risk based internal auditing on the effectiveness of the internal audit in regulatory state corporations in Kenya. The study concluded that the internal audit in RSCs in Kenya has strived and attained a good level of effectiveness. However, there were noted weaknesses in management support of the internal audit function, as well as the ability of the internal audit function to capture the needs of the management. This study will endeavor to examine the influence of internal audit independence on financial efficiency of selected county governments in Kenya as well as to find out the moderating influence of government policy on the relationship between internal audit independence and financial efficiency in County Governments. The study was conducted within the fourteen selected county governments targeting the County Government ministries.

\subsection{Statement of Research Problem}

In various industries, internal auditors face several obstacles including lack of independence, limited access to records support and recognition by the management. According to the Auditor General's Report (2017), the need for internal audit within the county government is underscored by noted irregularities within the county government expenditure (Auditor General, 2017). There have been several noted cases of misuse of public funds in the county governments and the lack of adherence to laid down procedures in the utilization of the funds. There has been utilization for public funds without examining the value for public funds yet internal audit reports had given a clean sheet indicating no irregularities with the same transactions. This raises questions of how independent are internal audit units at the county government in terms of accessibility to records, reporting structures, competencies and roles. Among the counties that have been mentioned to have misappropriation of public funds include Bungoma, Transzoia, Vihiga, Kakamega and Busia counties amongst others (Sheila, 2015). Several researchers carried out their work on internal audit independence. For example, Sarens (2016), in a survey of United States chief internal auditors, assessed the joint effect of audit committee independence and expertise on the committee's interaction with internal audit. They found that, independent committees with at least one member with accounting or finance expertise had longer meetings and more private meetings with the chief internal auditor. Goodwin and Yeo (2011) surveyed chief internal auditors in Singapore and found that audit committees that comprised solely of independent directors had more frequent meetings and more private meetings with the chief internal auditor thus denying him the expected independence. Goodwin (2013) obtained similar results in a survey of chief internal auditors from Australia and New Zealand and found that internal audit independence has no deep root on the financial performance of the Small and Medium Enterprises. Empirical evidence suggests that if left unexploited audit independence is most likely to adversely affect the financial efficiency of county governments. The research was conducted against the backdrop of increased regulation of public audit Act Kenya (2003), and other corporate Governance issues addressing widespread public outcry on financial mismanagement. In this regard therefore, the researcher carried out the study dealing with the influence of internal audit independence on the financial efficiency of selected county government. This has been an important unresolved issue and one that was further explored in this study. This study focused on the relationship between audit independence in terms of reporting structure and the financial efficiency of selected county governments in Kenya.

\subsection{Objectives of the Study:}

\subsubsection{General objective of the study}

The main objective of this study was to examine the influence of reporting structures on the financial efficiency of selected county governments. 


\subsubsection{Specific Objectives of the study}

The specific objectives was to:

i To determine the influence of reporting structures on the financial efficiency of the selected County Government.

\subsection{Research Hypothesis:}

In line with the objectives of the study, the following null hypotheses were tested:

$\mathbf{H}_{01}$ : There is no significant influence between reporting structures and financial efficiency in the selected County Governments.

\subsection{Conceptual Framework}

Conceptual framework is a hypothesized model identifying the model under study and the relationship between the dependent and independent variables (Mugenda \& Mugenda 2003).

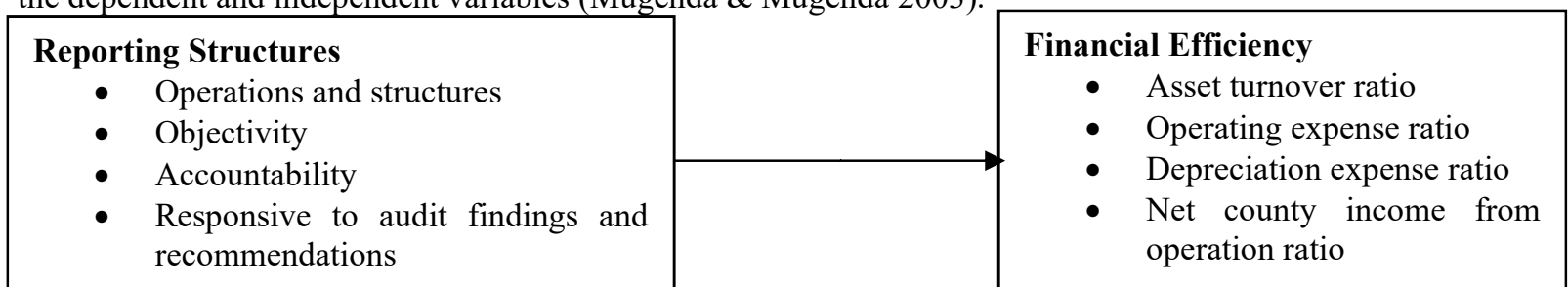

Source: Researchers own conceptualization

\subsection{LITERATURE REVIEW}

\subsection{Theoretical Framework}

\subsection{Agency Theory}

According to Meckling and Jensen (2000), agency relationship contract exists between one or more persons-the principal (s) and another person (agent) to perform some service on their behalf, which involves delegating some decision making authority to the agent. Agency theory evolution also owes much to the corporate governance literature, which analyzes the problem of separation of ownership and control (Grabling et al., 2004). In the county governance, internal audit independence plays an important role in reducing audit bias and corruption practices as well as audit queries by empirically confirming the validity of financial statements and agency problems. The principal- agent conflict is illustrated in agency theory, where principal (owner) lacks reasons to believe their agents (managers) due to information asymmetries and contradictory motives (Hillebrandt, 2000). The first proposers of the Agency theory were the Scholars Mitnick and Ross (2006). In their working paper Series University of Pittsburg they proposed that, a theory of agency be created and to actually begin its creation, independently and roughly concurrently. Ross is responsible for the origin of the economic theory of agency, and Mitnick for institutional theory of agency. This theory is anchored to explain the influence of managers in allowing or limiting reporting framework that ensures confidentiality, privacy and effectiveness of working for internal auditors among county governments.

\subsection{Reporting Structure and Financial Efficiency}

Management of various organizations always seek help from internal auditors to provide them with assurance that, risks are effectively identified and monitored, organizational process are effectively controlled, and Organizational processes are efficient or effective. In this structure, the internal audit function plays a unique role in organizations (Messier, 2011). According to Levitt (2010), the past internal audit literature often portrayed internal auditors as the representatives of the management on all financial matters. Internal control has taken on a broader meaning to include the crucial role played by top management in setting the tone at the top. Thus, internal auditors may find themselves conflicted in helping management to assess the effectiveness of their governance processes while reporting to the audit committee. The internal audit function has evolved in many organizations to a position where it is often called upon to take leadership in helping the organization implement, assess, or conceptualize risk management and control processes within an organization (Malan,2011). In some parts of the world such as United Kingdom and United States, recent legislation and stock exchange, proposals on better corporate governance have elevated the role of the audit committee to a prominent role in monitoring and reporting on the effectiveness of corporate governance. This has led to various recommendations that the internal audit function report directly to the audit committee, not to the management (Meckling, 2010).

A study by Breley et al. (2011) on internal audit reporting structure on effectiveness using descriptive and correlative survey designs with a sample of 128 respondents from the government agencies show that internal auditors should report to the highest level of organization to assure that corrective activities will be taken to implement internal audit recommendations. Lack of independence of internal auditors is an issue opposing internal 
audit performance. Particularly, they identified concerns about communication channels, reporting levels, and perceptions of independence.

Another study by Ahmad et al. (2009) focused on lack of independence in internal audit performance and increase in concerns, and how this lack of independence can affect the power of internal audit department using descriptive survey design on a sample of 483 respondents found that lack of independence reduces the quality of audit findings and ability to implement audit recommendations.

Another study by Kibet (2014) in a study on influence of audit independence on financial efficiency of banks in Kenya using survey design on a sample of 123 respondents revealed that there was greater variation in financial efficiency of commercial banks due to changes in internal audit reporting standards, independence of internal audit, professional competency and internal control. This shows that improvement in financial efficiency of commercial banks could be accounted for by changes in internal audit reporting standards, independence of internal audit, professional competency and internal control. It was also established that there was a strong positive relationship between financial performance of commercial banks and internal audit reporting standards, independence of internal audit, professional competency and internal control

Ongeri, Okioga, \& Okwena (2015) in a study on determinants of internal audit independence using descriptive survey design on a sample of 456 respondents observe that the internal auditors are highly influenced by their reporting positions and hence a reporting structure that includes the senior management is inappropriate but rather the internal auditors should report to the audit committees. Jie (2013) in a similar study on internal audit independence further observe that where the internal auditors are subject to incentives-based compensation, which include reported earnings as one measure of performance, their objectivity and independence may well be hampered.

\subsection{Financial Efficiency}

Financial Efficiency refers to the efficiency with which resources are correctly allocated among competing uses at a point of time. Financial Efficiency is a measure of how well an organization has managed certain tradeoffs (risk and return, liquidity and profitability) in the use of its financial resources. Financial Efficiency is regarded efficiency and is a management guide to greater efficiency the extent of profitability, productivity. It is interesting to note that sometimes, even sufficient profits can mask inefficiency and conversely, a good degree financial efficiency could be dressed with the absence \&profit. Some of the ratios used in measuring financial efficiency in the county governments include Asset turnover ratio, Operating expense ratio, Depreciation expense ratio and Net county income from operation ratio (Kelvin, 2012).

A number of studies have been conducted on the subject of financial efficiency with limited emphasis on county governments being new entities. Some of the key studies on this subject include the following; Cummins (2010) investigated the US insurance industry over the period of 1993-2006. The study questions whether it is better for insurers to provide both life-health and property-liability insurance services or to focus on one main industry branch. They estimate cost, revenue and profit efficiency by employing data envelopment analysis (DEA) and test for scope economies. The results imply that insurance companies should focus on core businesses instead of following conglomeration strategies.

Diacon et.al. (2012) investigated the effect of insurers' size on efficiency via cross-country comparisons. Using staff and capital resources as the main inputs and premiums and investment income as the main outputs, the study analyzes the average efficiency of insurance companies licensed in 15 European countries over the period of 1996-1999. The results reveal that very large or very small insurers are likely to be the most efficient ones in pure technical terms. In addition, the insurers operating in the UK, Spain, Sweden, and Denmark are likely to show highest average level of technical efficiency. Lastly, compared to their European rivals, the insurers of UK seem to produce low levels of scale and mix efficiency.

In a cross-country study, Fernandez et.al. (2012) examined the economic efficiency of 142 financial intermediaries from eighteen countries for the period 1989-1998 and the relationship between efficiency, productivity change and shareholders' wealth maximization by applying DEA. After estimating the relative efficiency of commercial banks of different geographical areas, they carry out a Malmquist decomposition in order to separate efficiency change from technical change. Their examination of the relationship between economic efficiency and wealth maximization reflects different productivity patterns among three geographical areas (North America, Japan and Europe), indicating that the estimates of economic efficiency and productivity changes are consistent with the wealth maximization criterion.

Applying DEA, Kirkwood and Nahm (2016) examined the cost efficiency of Australian banks.

In the study, they report an improved efficiency in the major banks despite little change in the efficiency of regional banks using multiple regression analysis. With respect to the relation between the measured changes in efficiency and stock returns, their results reveal that stock returns reflect efficiency changes. In addition to examining the relative cost and profit efficiencies of a panel of six Singapore listed banks by employing DEA, Chu \& Lim (2008) also investigate the existence of a statistical relationship between efficiency scores and how 
the shares of the banks performed in the marketplace using multiple regression analysis. They find that percentage changes in the prices of the bank shares reflect percentage changes in profit rather than cost efficiencies.

Abidin and Cabanda (2011) tested the efficiency performance of non-life insurers in Indonesia during the period of 2005-2007. Their results gathered from the DEA measurement show that bigger insurance firms appeared to have a higher efficiency score compared to their smaller counterparts. Their findings also confirm that, except for net premium margin (NPM); significant associations are exist between the value of DEA, return on assets (ROA), and return on equity (ROE). This implies that an increase in NPM results in a total efficiency increase.

Employing the cost efficiency method after Tone (2012), Sinha and Chatterjee (2009) investigated the cost efficiency of life insurance industry of India over two-year sub-sample periods between 2002 and 2007 using multiple regression analysis. The results of their analysis suggest an upward trend in cost efficiency on the sample of life insurance firms over the sub-sample periods of 2002-2003 and 2004-2005. On the other hand, the analysis shows a reverse trend for other two-year periods of 2005-2006 and 2006-2007. Barros and Obijiaku (2007) conducted both a technical and a scale efficiency analyses on a sample of Nigerian insurance firms for the period of 2001-2005. Utilizing the DEA method, they reach to conclude that large insurers produce higher efficiency scores than small insurers. As another finding, the study implies that insurance companies managed by a bank network tend to have higher efficiency scores compared to those not managed by a bank network. Lastly, the analysis reveals that insurers with higher market share operate more efficiently compared ones with lower market share.

\subsection{Research Methodology}

The design to be used in this study was a descriptive survey design where use of methods such as questionnaires and published data was made (Kombo and Tromp, 2006)). The study targeted 423 respondents from the 9 county Audit Committee members of the 47 county governments in Kenya. The researcher sampled 126 respondents from the $14(30 \%$ of the 47 targeted population of counties) counties which was purposively sampled regionally. Purposive sampling technique was used to get the 14 county governments. The survey involved collecting information by administering questionnaires. Data collected was descriptively analyzed using SPSS. Results was summarized using tables and presented in form of pie charts, graphs, and bar charts.

\subsection{DATA ANALYSIS AND DISCUSSIONS}

\subsection{Internal auditor's reporting structures and financial efficiency of selected county governments}

The objective of this study was to determine the influence of internal auditor's reporting structures and financial efficiency of selected county governments. To achieve this respondent were asked to give their opinions on how they agree or disagree with the statements in Likert scale of 1-5, where $1=$ Strongly Disagree, $2=$ Disagree, $3=$ not sure, 4= Agree, 5= Strongly Agree.

The study sought to investigate whether the independence of internal auditors in terms of operations and structures in selected county governments is significantly independent. It was realized, as seen in Table 7, that $0.0 \%$ (0) strongly disagreed, 1.6\% (2) disagreed, 0.0\% (0) were undecided, 18.8\% (23) agreed and 79.7\% (96) strongly agreed. A higher percentage of $98.5 \%$ (119), shows that most respondents agreed that the independence of internal auditors in terms of operations and structures in the selected county governments is significantly independent. However, $1.6 \%$ (2) disagreed.

The second item under this theme was to establish whether the structure of internal audit unit enhances objectivity. It was established, as seenTable 7, that $0.0 \%(0)$ strongly disagreed, $0.0 \%(0)$ disagreed, $0.0 \%(0)$ were undecided, 15.6\% (19) agreed and 84.4\% (102) strongly agreed. As indicated all, 100.0\% (121), of respondents agreed that the structure of internal audit unit enhances objectivity.

The third item under this theme was to establish whether the internal audit unit demonstrate that it recognizes its accountability to the audit committee. It was found that, as seenTable $7,0.0 \%(0)$ strongly disagreed, $0.0 \%(0)$ disagreed, $0.0 \%(0)$ was undecided, $12.5 \%$ (15) agreed and 87.5\% (106) strongly agreed. General, it was evident that $100.0 \%$ (121) of respondents agreed that the internal audit unit demonstrate that it recognizes its accountability to the audit committee

The study sought to establish whether management has been responsive to the committee's previous findings and recommendations. As illustrated in Table 7, the employees' responses were as follows: 0.0 (0) strongly disagreed, $1.6 \%$ (2) disagreed, $0.0 \%(0)$ were undecided, $12.5 \%$ (15) agreed and $85.9 \%$ (104) strongly agreed. Therefore, a majority of respondents $98.4 \%$ (119) generally agreed that management has been responsive to the committees' previous findings and recommendations.

In establishing whether the internal audit unit reports to the highest authority in the county, the study realized, as seenTable 7 , that $0.0 \%(0)$ strongly disagreed, $0.0 \%(0)$ disagreed, $0.0 \%(0)$ were undecided, $22.2 \%(27)$ agreed and $77.8 \%(94)$ strongly agreed. This finding indicate that all respondents agreed, as seen from the high percentage $100.0 \%$ (121), that the internal audit unit reports to the highest authority in the.

In establishing whether there is political and administrative interference in the operations of the audit unit, 
the study realized, as seenTable 7 , that $0.0 \%(0)$ strongly disagreed, $0.0 \%(0)$ disagreed, $0.0 \%(0)$ were undecided, $20.3 \%$ (25) agreed and 79.7\% (96) strongly agreed. This finding indicate that all respondents agreed, as seen from the high percentage $100.0 \%$ (121), that there is political and administrative interference in the operations of the audit unit.

The last item under this theme was to determine whether the reporting structure in this county needs re alignemnt. It was established, as tabulated in Table 7 that $15.6 \%$ (19) strongly disagreed, $84.4 \%$ (102) disagreed, $0.0 \%(0)$ were undecided, $0.0 \%(0)$ agreed and $0.0 \%(0)$ strongly agreed. As indicated all respondents $100.0 \%$ (121), were of the opinion that the reporting structure in this county needs re alignemnt.

The last item under this theme was to establish whether they disseminate their findings from internal audit activiities to relevant stakeholders in the county. It was found that, as seenTable $7,0.0 \%(0)$ strongly disagreed, $0.0 \%(0)$ disagreed, $0.0 \%(0)$ was undecided, $12.5 \%$ (15) agreed and 87.5\% (106) strongly agreed. General, it was evident that $100.0 \%$ (121) of respondents agreed that they disseminate ther findings from internal audit activiities to relevant stakeholders in the county.

The above findings are in line with findings of previous studies by Breley et al. (2011) on Internal audit reporting structure on effectiveness using descriptive and correlative survey designs with a sample of 128 respondents from the government agencies which showed that internal auditors should report to the highest level of organization to assure that corrective activities will be taken to implement internal audit recommendations. Lack of independence of internal auditors is an issue opposing internal audit performance. Particularly, they identified concerns about communication channels, reporting levels, and perceptions of independence. The findings for this objective were tabulated in Table 7

Table 1: Influence of reporting structures and financial efficiency of selected county governments

\begin{tabular}{|c|c|c|c|c|c|c|c|}
\hline NO. & Description & SD & D & $\mathbf{U}$ & $\mathbf{A}$ & SA & Total \\
\hline 1. & $\begin{array}{l}\text { The independence of internal auditors in terms of } \\
\text { operations and structures in the selected county } \\
\text { governments is significantly independent }\end{array}$ & $\begin{array}{l}0.0 \% \\
(0)\end{array}$ & $\begin{array}{l}1.6 \% \\
(2)\end{array}$ & $\begin{array}{l}0.0 \% \\
(0)\end{array}$ & $\begin{array}{l}18.8 \% \\
(23)\end{array}$ & $\begin{array}{l}79.7 \% \\
(96)\end{array}$ & $\begin{array}{l}100.0 \% \\
(121)\end{array}$ \\
\hline 2. & $\begin{array}{l}\text { The structure of internal audit unit enhances } \\
\text { objectivity }\end{array}$ & $\begin{array}{l}0.0 \% \\
(0)\end{array}$ & $\begin{array}{l}0.0 \% \\
(0)\end{array}$ & $\begin{array}{l}0.0 \% \\
(0)\end{array}$ & $\begin{array}{l}15.6 \% \\
(19)\end{array}$ & & $\begin{array}{l}100.0 \% \\
(121)\end{array}$ \\
\hline 3. & $\begin{array}{l}\text { The internal audit unit demonstrate that it recognizes } \\
\text { its accountability to the audit committee }\end{array}$ & $\begin{array}{l}0.0 \% \\
(0)\end{array}$ & $\begin{array}{l}0.0 \% \\
(0)\end{array}$ & $\begin{array}{l}0.0 \% \\
(0)\end{array}$ & $\begin{array}{l}12.5 \% \\
(15)\end{array}$ & & $\begin{array}{l}100.0 \% \\
(121)\end{array}$ \\
\hline 4. & the committees & $\begin{array}{l}0.0 \% \\
(0)\end{array}$ & $\begin{array}{l}1.6 \% \\
(2)\end{array}$ & $\begin{array}{l}0.0 \% \\
(0)\end{array}$ & & & \\
\hline 5. & unit reports to the highest authority & $\begin{array}{l}0.0 \% \\
(0)\end{array}$ & $\begin{array}{l}0.0 \% \\
(0)\end{array}$ & & $\begin{array}{l}22.2 \% \\
(27)\end{array}$ & $\begin{array}{l}77.8 \% \\
(94)\end{array}$ & $\begin{array}{l}100.0 \% \\
(121)\end{array}$ \\
\hline 6. & $\begin{array}{l}\text { There is political and administrative interference in } \\
\text { the operations of the audit unit }\end{array}$ & $\begin{array}{l}0.0 \% \\
(0)\end{array}$ & $\begin{array}{l}0.0 \% \\
(0)\end{array}$ & $\begin{array}{l}0.0 \% \\
(0)\end{array}$ & $\begin{array}{l}20.3 \% \\
(25)\end{array}$ & $\begin{array}{l}79.7 \% \\
(96)\end{array}$ & $\begin{array}{l}100.0 \% \\
(121)\end{array}$ \\
\hline 7. & $\begin{array}{l}\text { The reporting structure in this county needs re } \\
\text { alignemnt }\end{array}$ & $\begin{array}{l}15.6 \% \\
(19)\end{array}$ & $\begin{array}{l}84.4 \% \\
(102)\end{array}$ & $\begin{array}{l}0.0 \% \\
(0)\end{array}$ & $\begin{array}{l}0.0 \% \\
(0)\end{array}$ & $\begin{array}{l}0.0 \% \\
(0)\end{array}$ & $\begin{array}{l}100.0 \% \\
(121)\end{array}$ \\
\hline 8. & $\begin{array}{l}\text { We disseminate our findings from internal audit } \\
\text { activiities to relevant stakeholders in the county }\end{array}$ & & $\begin{array}{l}0.0 \% \\
(0)\end{array}$ & $\begin{array}{l}0.0 \% \\
(0)\end{array}$ & $\begin{array}{l}0.0 \% \\
(0)\end{array}$ & $\begin{array}{l}12.5 \% \\
(15)\end{array}$ & $\begin{array}{l}87.5 \% \\
(106)\end{array}$ \\
\hline
\end{tabular}

\subsection{Financial Efficiency of Selected County Governments}

The dependent variable of this study was financial efficiency of selected county governments. To achieve this respondent were asked to give their opinions on how they agree or disagree with the statements in Likert scale of 1-5, where 1= Strongly Disagree, $2=$ Disagree, $3=$ not sure, $4=$ Agree, $5=$ Strongly Agree .

The study sought to investigate whether the respondent's current revenue collection has grown due to effective internal audit. It was realized, as seen in Table 10, that $0.0 \%(0)$ strongly disagreed, $1.6 \%(2)$ disagreed, $0.0 \%(0)$ were undecided, $18.8 \%$ (23) agreed and 79.7\% (96) strongly agreed. A higher percentage of 98.5\% (119), shows that most respondents agreed that their current revenue collection has grown due to effective internal audit. However, $1.6 \%$ (2) disagreed.

The second item under this theme was to establish whether the internal audit independence has led to improved management of public resources. It was established, as seenTable 10 , that $0.0 \%(0)$ strongly disagreed, $0.0 \%(0)$ disagreed, $0.0 \%(0)$ were undecided, $15.6 \%$ (19) agreed and 84.4\% (102) strongly agreed. As indicated all, $100.0 \%$ (121), of respondents agreed that their iinternal audit independence has led to improved management of public resources.

The third item under this theme was to establish whether the Internal auditing independence has increased Budget absorption rate for the projects implemented. It was found that, as seenTable $10,0.0 \%(0)$ strongly disagreed, $0.0 \%(0)$ disagreed, $0.0 \%(0)$ was undecided, $12.5 \%(15)$ agreed and $87.5 \%(106)$ strongly agreed. General, it was evident that $100.0 \%$ (121) of respondents agreed that the internal auditing independence has increased Budget absorption rate for the projects implemented The study sought to establish whether there has 
been increased transparency and accountability in the use of their gross county revenue due to internal audit independence. As illustrated in Table 10, the employees' responses were as follows: $0.0(0)$ strongly disagreed, $1.6 \%$ (2) disagreed, $0.0 \%(0)$ were undecided, $12.5 \%$ (15) agreed and $85.9 \%$ (104) strongly agreed. Therefore, a majority of respondents $98.4 \%$ (119) generally agreed that there has been increased transparency and accountability in the use of their gross county revenue due to internal audit independence.

In establishing whether the departments have been able to control their expenditure due to presence of an independent internal audit mechanism, the study realized, as seenTable 10, that $0.0 \%(0)$ strongly disagreed, $0.0 \%$ (0) disagreed, $0.0 \%(0)$ were undecided, $22.2 \%(27)$ agreed and $77.8 \%(94)$ strongly agreed. This finding indicate that all respondents agreed, as seen from the high percentage $100.0 \%$ (121), that the departments have been able to control their expenditure due to presence of an independent internal audit mechanism.

In establishing whether management and control of county assets and equipment has improved due to the independence of internal audit, the study realized, as seenTable 10, that $0.0 \%(0)$ strongly disagreed, $0.0 \%(0)$ disagreed, $0.0 \%(0)$ were undecided, 20.3\% (25) agreed and 79.7\%(96) strongly agreed. This finding indicate that all respondents agreed, as seen from the high percentage $100.0 \%$ (121), that Management and control of county assets and equipment has improved due to the independence of internal audit.

This item under this theme was to determine whether the reporting structure in this county needs re alignemnt. It was established, as tabulated in Table 10 that $15.6 \%$ (19) strongly disagreed, $84.4 \%(102)$ disagreed, $0.0 \%(0)$ were undecided, $0.0 \%(0)$ agreed and $0.0 \%(0)$ strongly agreed. As indicated all respondents $100.0 \%(121)$, were of the opinion that the reporting structure in this county needs re alignemnt.

This item under this theme was to establish whether there has been reduced incidence of embezzlement of funds and corruption due to a vibrant internal audit independent mechanist. It was found that, as seenTable 10 , $0.0 \%(0)$ strongly disagreed, $0.0 \%(0)$ disagreed, $0.0 \%(0)$ was undecided, $12.5 \%(15)$ agreed and $87.5 \%(106)$ strongly agreed. General, it was evident that $100.0 \%$ (121) of respondents agreed that there has been reduced incidence of embezzlement of funds and corruption due to a vibrant internal audit independent mechanism.

The above findings are in line with findings of previous studies by Fernandez et.al. (2012) on The relationship between efficiency, productivity change and shareholders' wealth maximization by applying DEA Examined the economic efficiency of 142 financial intermediaries from eighteen countries for the period 1989-1998 found that their examination of the relationship between economic efficiency and wealth maximization reflects different productivity patterns among three geographical areas (North America, Japan and Europe), indicating that the estimates of economic efficiency and productivity changes are consistent with the wealth maximization criterion using descriptive and correlative survey designs with a sample of 128 respondents from the government agencies which showed that internal auditors should report to the highest level of organization to assure that corrective activities will be taken to implement internal audit recommendations. Lack of independence of internal auditors is an issue opposing internal audit performance. Particularly, they identified concerns about communication channels, reporting levels, and perceptions of independence. The findings for this objective were tabulated in Table 10.

Table 2: Financial efficiency of selected county governments

\begin{tabular}{|c|c|c|c|c|c|c|c|}
\hline NO. & Description & SD & D & $\mathbf{U}$ & $\mathbf{A}$ & SA & Total \\
\hline 1 & $\begin{array}{l}\text { Our current revenue collection has grown due to } \\
\text { effective internal audit? }\end{array}$ & $\begin{array}{l}0.0 \% \\
(0)\end{array}$ & $\begin{array}{l}1.6 \% \\
(2)\end{array}$ & $\begin{array}{l}0.0 \% \\
(0)\end{array}$ & $\begin{array}{l}18.8 \% \\
(23)\end{array}$ & $\begin{array}{l}79.7 \% \\
(96)\end{array}$ & $\begin{array}{l}100.0 \% \\
(121)\end{array}$ \\
\hline 2 & $\begin{array}{l}\text { Internal audit independence has led to improved } \\
\text { management of public resources? }\end{array}$ & $\begin{array}{l}0.0 \% \\
(0)\end{array}$ & $\begin{array}{l}0.0 \% \\
(0)\end{array}$ & $\begin{array}{l}0.0 \% \\
(0)\end{array}$ & $\begin{array}{l}15.6 \% \\
(19)\end{array}$ & $\begin{array}{l}84.4 \% \\
(102)\end{array}$ & $\begin{array}{l}100.0 \% \\
(121)\end{array}$ \\
\hline 3 & $\begin{array}{l}\text { Internal auditing independence has increased Budget } \\
\text { absorption rate for the projects implemented? }\end{array}$ & $\begin{array}{l}0.0 \% \\
(0)\end{array}$ & $\begin{array}{l}0.0 \% \\
(0)\end{array}$ & $\begin{array}{l}0.0 \% \\
(0)\end{array}$ & $\begin{array}{l}12.5 \% \\
(15)\end{array}$ & $\begin{array}{l}87.5 \% \\
(106)\end{array}$ & $\begin{array}{l}100.0 \% \\
(121)\end{array}$ \\
\hline 4 & $\begin{array}{l}\text { There has been increased transparency and } \\
\text { accountability in the use of our gross county revenue } \\
\text { due to internal audit independence }\end{array}$ & $\begin{array}{l}0.0 \% \\
(0)\end{array}$ & $\begin{array}{l}1.6 \% \\
(2)\end{array}$ & $\begin{array}{l}0.0 \% \\
(0)\end{array}$ & $\begin{array}{l}12.5 \% \\
(15)\end{array}$ & $\begin{array}{l}85.9 \% \\
(104)\end{array}$ & $\begin{array}{l}100.0 \% \\
(121)\end{array}$ \\
\hline 5 & $\begin{array}{l}\text { Departments have been able to control their } \\
\text { expenditure due to presence of an independent internal } \\
\text { audit mechanism }\end{array}$ & $\begin{array}{l}0.0 \% \\
(0)\end{array}$ & $\begin{array}{l}0.0 \% \\
(0)\end{array}$ & $\begin{array}{l}0.0 \% \\
(0)\end{array}$ & $\begin{array}{l}22.2 \% \\
(27)\end{array}$ & $\begin{array}{l}77.8 \% \\
(94)\end{array}$ & $\begin{array}{l}100.0 \% \\
(121)\end{array}$ \\
\hline 6 & $\begin{array}{l}\text { Management and control of county assets and } \\
\text { equipment has improved due to the independence of } \\
\text { internal audit }\end{array}$ & $\begin{array}{l}0.0 \% \\
(0)\end{array}$ & $\begin{array}{l}0.0 \% \\
(0)\end{array}$ & $\begin{array}{l}0.0 \% \\
(0)\end{array}$ & $\begin{array}{l}20.3 \% \\
(25)\end{array}$ & $\begin{array}{l}79.7 \% \\
(96)\end{array}$ & $\begin{array}{l}100.0 \% \\
(121)\end{array}$ \\
\hline 7 & $\begin{array}{l}\text { There has been reduced incidence of embezzlement of } \\
\text { funds and corruption due to a vibrant internal audit } \\
\text { independent mechanism }\end{array}$ & $\begin{array}{l}15.6 \% \\
(19)\end{array}$ & $\begin{array}{l}84.4 \% \\
(102)\end{array}$ & $\begin{array}{l}0.0 \% \\
(0)\end{array}$ & $\begin{array}{l}0.0 \% \\
(0)\end{array}$ & $\begin{array}{l}0.0 \% \\
(0)\end{array}$ & $\begin{array}{l}100.0 \% \\
(121)\end{array}$ \\
\hline 8 & $\begin{array}{l}\text { There is improved trust and confidence by the public } \\
\text { in the county government due to improved service } \\
\text { delivery due to the independence of internal audit } \\
\text { department }\end{array}$ & & $\begin{array}{l}0.0 \% \\
(0)\end{array}$ & $\begin{array}{l}0.0 \% \\
(0)\end{array}$ & $\begin{array}{l}0.0 \% \\
(0)\end{array}$ & $\begin{array}{l}12.5 \% \\
(15)\end{array}$ & $\begin{array}{l}87.5 \% \\
(106)\end{array}$ \\
\hline
\end{tabular}




\subsection{Inferential Statistics}

\subsubsection{Reporting structures and Financial Efficiency of County Governments}

The means of reporting structures and Financial Efficiency of County Governments were regressed. The purpose of this analysis was to find the relationship between reporting structures and Financial Efficiency of County Governments. This aided in testing the second hypothesis of the study that posits, $\mathrm{H}_{0} 2$ : Reporting structures has no significant effect on Financial Efficiency of County Governments. This was tested using significance of $\mathrm{R}$ square and Regression coefficient at $95.0 \%$ confidence level. The results are presented in Table 4.13.

Table 4.14 reveals that the relationship of reporting structures and Financial Efficiency of County Governments variables which was linear, positive and significant. The correlation coefficient (R) of 0.470 implied a relatively weak relationship of reporting structures and Financial Efficiency of County Governments. The coefficient of determination, R-square of 0.221 implied that $22.1 \%$ of the variance in Financial Efficiency of County Governments was accounted for by reporting structures with the significance value of $p=0.000$ which is less than 0.05 . The unstandardized regression coefficient $(\beta)$ value of reporting structures and Financial Efficiency of County Governments was 0.384 , correlation coefficient $(\beta)$ of 0.470 and with a t-test of 9.789 and significance level of $\mathrm{p}=0.000$, which further confirmed existence of a significant and relatively weak positive linear correlation of reporting structures and Financial Efficiency of County Governments

Table 3: Regression Results of Reporting structures and Financial Efficiency of County Governments Model Summary ${ }^{c}$

\begin{tabular}{lccccccccc}
\hline Model & $\mathrm{R}$ & \multicolumn{2}{c}{$\mathrm{R}$} & \multicolumn{2}{c}{ Adjusted R } & Std. Error of the & \multicolumn{5}{c}{ Change statistics } \\
\cline { 6 - 9 } & & Square & Square & Estimate & R Square change F change & df1 & df2 & Sig. F change \\
\hline 1 & $0.470^{\mathrm{a}}$ & 0.221 & 0.219 & 0.78899 & 0.221 & 95.821 & 1 & 338 & .000 \\
\hline
\end{tabular}

a. a. Predictors: (Constant), Reporting structures

b. c. Dependent Variable: Financial Efficiency of County Governments

\begin{tabular}{|c|c|c|c|c|c|c|}
\hline \multicolumn{7}{|c|}{ ANOVA $^{a}$} \\
\hline Model & & Sum of Squares & $\mathrm{df}$ & Mean Square & $\mathrm{F}$ & Sig. \\
\hline \multirow{3}{*}{1} & Regression & 59.649 & 1 & 59.649 & 95.821 & $.000^{\mathrm{b}}$ \\
\hline & Residual & 210.407 & 338 & 0.623 & & \\
\hline & Total & 270.056 & 339 & & & \\
\hline
\end{tabular}

a. Dependent Variable: Financial Efficiency of County Governments

c. b. Predictors: (Constant), Reporting structures

Coefficients $^{\text {a }}$

\begin{tabular}{|c|c|c|c|c|c|c|c|c|c|}
\hline \multirow{2}{*}{\multicolumn{2}{|c|}{ Model }} & \multicolumn{2}{|c|}{$\begin{array}{l}\text { Unstandardized } \\
\text { Coefficients }\end{array}$} & \multirow{2}{*}{$\begin{array}{c}\text { Standardized } \\
\text { Coefficients } \\
\text { Beta }\end{array}$} & \multirow[t]{2}{*}{$\mathrm{T}$} & \multirow[t]{2}{*}{ Sig. } & \multicolumn{3}{|c|}{ Correlations } \\
\hline & & $\mathrm{B}$ & S.E. & & & & Zero order & Partial & Part \\
\hline \multirow[b]{2}{*}{1} & (Constant) & 2.322 & 0.145 & & 16.000 & 0.000 & & & \\
\hline & $\begin{array}{l}\text { Reporting } \\
\text { structures }\end{array}$ & 1.384 & 0.039 & 0.470 & 9.789 & 0.000 & 0.470 & 0.470 & 0.470 \\
\hline
\end{tabular}

a. Dependent Variable: Financial Efficiency of County Governments

b. Predictors: (Constant), Reporting structures

This indicated that a unit change in reporting structures would result to change in Financial Efficiency of County Governments by 1.384 in the same direction. At 5\% level of significance and $95 \%$ level of confidence, reporting structures was significant in predicating the degree of Financial Efficiency of County Governments.

An F-significance value of $p=0.000$ was established showing that there was a probability of $0.00 \%$ from the regression model to accept the null hypothesis. The hypothesis, $\mathrm{H}_{0} 2$, stated that: Reporting structures has no significant effect on Financial Efficiency of County Governments. Thus, the model was found significant and therefore the null hypothesis was rejected on the ground that reporting structures had significant and relatively weak and positive linear correlation with Financial Efficiency of County Governments. The second research hypothesis was tested using the significance level of both the $\mathrm{R}^{2}$ and regression coefficients at 0.05 .

The study conducted multiple regression on the influence of reporting structures and financial efficiency of selected county governments. The results in relation to the foregoing are illustrated in Tables 4.15. 
Table 4: Regression Coefficients ${ }^{\mathrm{a}}$

\begin{tabular}{llllll}
\hline & \multicolumn{2}{l}{ Unstandardized Coefficients } & \multicolumn{2}{l}{$\begin{array}{l}\text { Standardized } \\
\text { Coefficients }\end{array}$} & \\
\cline { 2 - 4 } Model & B & Std. Error & Beta & T & Sig. \\
\hline 1 (Constant) & 1.420 & 0.448 & & 3.166 & 0.000 \\
Reporting structure & 0.384 & 0.197 & 0.232 & 1.107 & 1.43 \\
\hline
\end{tabular}

a. Dependent Variable: Financial efficiency

The interpretation of the findings is shown in the following regression models.

$\mathrm{Y}=\beta_{0}+\beta_{1} \mathrm{X}_{1}+\varepsilon$

$\mathrm{Y}=1.420+0.384 \mathrm{X}_{1}+\varepsilon$

It was noted that a unit increase in financial efficiency would require 3.166 increase in reporting structures.

\subsection{SUMMARY OF FINDINGS, CONCLUSIONS AND RECOMMENDATIONS}

5.1. Internal Auditors Reporting Structures and the financial efficiency of the selected County Governments The objective of this study was to determine the influence of internal auditor's reporting structures and financial efficiency of selected county governments. The study sought to investigate whether the independence of internal auditors in terms of operations and structures in selected county governments is significantly independent. A higher percentage of $98.5 \%$ (119), shows that most respondents agreed that the independence of internal auditors in terms of operations and structures in the selected county governments is significantly independent respectively. However, $1.6 \%$ (2) disagreed.

The second item under this theme was to establish whether the structure of internal audit unit enhances objectivity. As indicated all, $100.0 \%$ (121), of respondents agreed that the structure of internal audit unit enhances objectivity. The third item under this theme was to establish whether the internal audit unit demonstrate that it recognizes its accountability to the audit committee. General, it was evident that $100.0 \%$ (121) of respondents agreed that the internal audit unit demonstrate that it recognizes its accountability to the audit committee respectively

The study sought to establish whether management has been responsive to the committee's previous findings and recommendations. A majority of respondents 98.4\% (119) generally agreed that management has been responsive to the committees' previous findings and recommendations. In establishing whether the internal audit unit reports to the highest authority in the county. This finding indicate that all respondents agreed, as seen from the high percentage $100.0 \%(121)$, that the internal audit unit reports to the highest authority in the county.

In establishing whether there is political and administrative interference in the operations of the audit unit. This finding indicate that all respondents agreed, as seen from the high percentage $100.0 \%$ (121), that there is political and administrative interference in the operations of the audit unit.

The sixth item under this theme was to determine whether the reporting structure in this county needs re alignemnt. It was established as indicated all respondents $100.0 \%$ (121), were of the opinion that the reporting structure in this county needs re alignemnt.

The last item under this theme was to establish whether they disseminate their findings from internal audit activiities to relevant stakeholders in the county. General, it was evident that $100.0 \%$ (121) of respondents agreed that they disseminate ther findings from internal audit activiities to relevant stakeholders in the county.

\subsection{Financial Efficiency of selected county governments}

The dependent variable of the study was financial efficiency in the selected county governments. Respondent were asked to give their opinions on how they agree or disagree with the statements

Respondents were asked to state their observation on whether internal auditors have an un-limited access to information they are supposed to audit. Majority $45.3 \%$ (55) of the respondents generally agreed that internal auditors have an un-limited access to information they are supposed to audit. However, 26.6\% (33) generally disagreed.

The study sought to investigate whether the internal auditor is a very important function in governance. As indicated by the high percentage $95.4 \%$ (115), majority of respondents agreed that the internal auditor is a very important function in governance. However, $0.0 \%(0)$ disagreed.

The third item under this theme was to establish whether the internal audit independence in their department has failed. Majority of respondents agreed that the internal audit independence in our department has failed. However, $0.0 \%(0)$ disagreed.

The fourth item under this theme was to establish whether the internal audit's overall performance in their organization is very satisfactory. General, it was evident that $100.0 \%$ (121) of respondents agreed that the internal audit's overall performance in their organization is very satisfactory. 
The study sought to establish whether their roles as internal auditors are well understood by county government departments. Majority of the respondents 100\% (119) generally agreed that their roles as internal auditors are well understood by county government departments.

In establishing whether their responsibilities as internal auditors are appreciated by county government departments. Majority of respondents agreed, as seen from the high percentage 98.4\% (119), that their responsibilities as internal auditors are appreciated by county government departments.

The seventh item under this theme was to determine whether the internal auditors are looked at with suspicion and isolation by county. As indicated by the high percentage $96.9 \%$ (117), majority of respondents agreed that internal auditors are looked at with suspicion and isolation by county. However, $1.6 \%$ (2) disagreed.

The study sought to investigate whether understanding and appreciating internal audit roles significantly influence financial efficiency in county. As indicated by the high percentage $95.4 \%$ (115), majority of respondents agreed that understanding and appreciating internal audit roles significantly influence financial efficiency in county governments. However, $0.0 \%(0)$ disagreed.

\subsection{Conclusions}

\subsubsection{Internal auditor's reporting structures and financial efficiency of selected county governments}

The objective of this study was to determine the influence of internal auditor's reporting structures and financial efficiency of selected county governments. The means of reporting structures and Financial Efficiency of County Governments were regressed. Findings revealed that the relationship of reporting structures and Financial Efficiency of County Governments variables which was linear, positive and significant. The correlation coefficient (R) of 0.470 implied a relatively weak relationship of reporting structures and Financial Efficiency of County Governments. The coefficient of determination, R-square of 0.221 implied that $22.1 \%$ of the variance in Financial Efficiency of County Governments was accounted for by reporting structures with the significance value of $p=$ 0.000 which is less than 0.05 . The unstandardized regression coefficient $(\beta)$ value of reporting structures and Financial Efficiency of County Governments was 0.384 , correlation coefficient $(\beta)$ of 0.470 and with a t-test of 9.789 and significance level of $p=0.000$, which further confirmed existence of a significant and relatively weak positive linear correlation of reporting structures and Financial Efficiency of County Governments. The model was found significant and therefore the null hypothesis was rejected on the ground that reporting structures had significant and relatively weak and positive linear correlation with Financial Efficiency of County Governments. The second research hypothesis was tested using the significance level of both the $\mathrm{R}^{2}$ and regression coefficients at 0.05 .

\subsection{Recommendations}

The International Standards for the Professional Practice of Internal Auditing (The Standards) established by The Institute of Internal Auditors (The IIA) state that IA should be independent. Indeed, independence guarantees IA's freedom in defining its activities, in executing the work plan, in accessing staff and information without limitations, and in the reporting of findings. Regarding Find, practices described above concur with the Standards since they show that IA independence is a key factor to ensure its effectiveness in prevention, detection and reporting of such cases. To achieve this independence, the Standards recommend that the Chief Audit Executive reports to a level within the organization that allows the internal audit activity to fulfil its responsibilities. Practices described above provide some proposals for action which could be considered by ministries to strengthen the independence of their IA services. As illustrated by the majority of surveyed respondents, IA should report to the highest level within the entity, namely the minister or equivalent. In addition, as is the case in the majority of sampled ministries, the existence of an IA function within the ministry, and its line of reporting to the highest level, should be a legal requirement, and not subject to management's decision within the ministry. This reporting line should be formalized in the internal audit mandate

\section{REFERENCES}

Ahmad, H., Othman, R., \& Jusoff, K. (2009). The effectiveness of internal audit in Malaysian public sector.Journal of Modern Accounting and Auditing, 5(9), 53-62.

Alizeban, N. (2014). Threats to auditor independence. The Malaysian Accounting: Journal of Malaysian Institute of Certfied Pulic Accounting, 3(5), 543-599.

Alzeban, A., \& Gwilliam, D. (2014). Factors affecting the internal audit effectiveness: A survey of the Saudi public sector. Journal of International Accounting, Auditing and Taxation, 23(2), 7486.http://dx.doi.org/10.1016/j.intaccaudtax.2014.06.001

Goodwin, J. (2011). Two factors affecting internal audit independence and objectivity: Evidence from Singapore. International Journal of auditing, 107-125.

Institute of Internal Auditors. (2011). Professional internal Auditing standards volume. Standards for the professional practice of internal Auditing. Institute of internal Auditors. 
Kothari, C. (2005). Research Methodology, Methods and Techniques. 2nd Revised Ed. New Delhi, India: New Age international publishers.

Mihret, D., \& Woldeyohannis, G. (2008). Value-added role of internal audit: An Ethiopian case study.Managerial Auditing Journal, 23(6), 567-595.

Mugenda and Mugenda. (2003). Research methods: Quantitative and qualitative Approaches. Nairobi: Act press. Sheiv (2010). Auditor independence.The challenges of fact and appearence. Singapore: Acconting Horizons. 